\title{
ע Sateenkaariperheiden äitien kokemuksia perheensä elämästä ja siihen yhteydessä olevista tekijöistä - integratiivinen kirjallisuuskatsaus
}

Tämän integratïvisen kirjallisuuskatsauksen tarkoituksena on kuvata sateenkaariperheiden äitien kokemuksia perheensä elämästä ja siihen yhteydessä olevista tekijöistä aiempien kansainvälisten tutkimusten avulla. Katsaus on tarpeen, koska esimerkiksi terveydenhuoltohenkilökunnan on tärkeä tunnistaa erilaiset perheet ja niiden todellisuus sellaisena kuin perheet sen itse kokevat. Lisäksi heillä on oltava riittävästi tietoa erilaisista perheistä kyetäkseen tukemaan näitä perheitä. Systemaattinen tiedonhaku suoritettiin Cinahl, Medline, PsycINF0, Linda, Arto ja Medic -tietokannoista ja aineistoon valittiin yhteensä 49 tutkimusartikkelia kahdeksasta eri maasta. Aineisto analysoitiin temaattisella analyysilla. Äitien kokemukset perheensä elämästä osana yhteiskuntaa muodostuivat kolmesta ulottuvuudesta: eläminen perinteisestä heteroydinperheestä poikkeavassa perheessä, eläminen vähemmistöasemasta aiheutuvien ennakkokäsitysten kanssa ja selviytyminen sateenkaariperheenä. Eläminen perinteisestä heteroydinperheestä poikkeavassa perheessä merkitsi äitien keskinäisten roolien etsimistä ja tasapainon vahvistamista sekä elämistä sosiaalisena äitinä ja vanhempana, jota ei tunnusteta eikä tunnisteta. Äitien kokemukset elämisestä vähemmistöasemasta aiheutuvien ennakkokäsitysten kanssa olivat kolmenlaisia: ympäristön suhtautumiseen kohdistuvat pelot, kohtaamiset ihmisten kanssa, joilla oli ennakkokäsityksiä sekä kokemus siitä, että heidän kohtaamansa asiat olivat aiheuttaneet seurauksia perheenjäsenten terveydelle ja hyvinvoinnille. Selviytyminen sateenkaariperheenä sisälsi äitien aktiivista toimintaa perheensä selviytymisen parantamiseksi ja selviytymistä vaihtelevan sosiaalisen ja yhteiskunnallisen tuen kanssa. Tämän tutkimuksen tulosten perusteella voidaan tunnistaa sateenkaariperheiden äideillä olevan tuen tarpeissaan erityispiirteitä. Ne kohdistuvat vanhemmuuteen ja parisuhteeseen, äitien seksuaalisen identiteettiin ja perheen lähipiiriin. Lisäksi ne kohdistuvat sosiaalisen äidin roolin vahvistamiseen, perheen tunnistamiseen ja normaaliuden tunteen kokemiseen sekä koulutusvastuun jakamiseen sateenkaariperhemuodosta yhdessä äitien kanssa. Jatkossa on tutkittava empiirisesti suomalaisten sateenkaariperheiden äitien kokemusta perheidensä elämästä osana suomalaista yhteiskuntaa.

ASIASANAT: sateenkaariperheet, äidit, lesbous, biseksuaalisuus, vanhempi-lapsi suhde, parisuhde

RIIKKA APIAINEN, PÄIVI ASTEDT-KURKI, MIRA PALONEN, JARI KYLMÄ 


\section{TUTKIMUKSEN LÄHTÖKOHDAT}

Sukupuoli- ja seksuaalivähemmistöihin kuuluvien vanhempien lapsiperheitä kutsutaan sateenkaariperheiksi $(1,2)$. Sateenkaariperheen käsitteellä korostetaan perheiden monimuotoisuutta. Vaikka sateenkaariperheet ovat erilaisia, niillä on myös yhteisiä tekijöitä. Lasten hankkiminen harkitaan tarkoin ja kasvatukseen sitoudutaan voimakkaasti. (3.) Sateenkaariperheille on yhteistä myös se, että biologinen, sosiaalinen, juridinen ja käytännöllinen vanhemmuus eivät toteudu välttämättä päällekkäin perheessä (1): joku vanhemmista saattaa olla vailla juridista vanhemmuutta, mutta käytännöllinen vanhemmuus saattaa toteutua hänen kohdallaan joka päiväisessä elämässä. Sateenkaariperheet saattavat näyttäytyä ongelmallisina suhteessa yhteiskunnallisiin normeihin ja ihanteisiin, koska esimerkiksi heteroseksuaalinen normi ei toteudu näissä perheissä (4).

Sateenkaariperheiden määrä on kasvanut koko 2000-luvun ajan (4). Sateenkaariperheet ja erityisesti lasten asema näissä perheissä herättää kuitenkin yhteiskunnallista keskustelua. Taloustutkimuksen tasa-arvoiseen avioliittolakiin liittyvän Tahdon2013-hankkeen (5) yhteydessä teettämän galluptutkimuksen mukaan reilu kolmannes suomalaisista ei olisi halunnut antaa samaa sukupuolta oleville rekisteröidyille pareille adoptio-oikeutta. Suomalaisten mielipiteet miesja naispareja kohtaan ovat suvaitsevammat kuin mies- ja naisparien vanhemmuutta kohtaan. Yli puolet suomalaisista näkee mies- ja naisparien vanhemmuuden huonompana kuin heterovanhempien. Nämä mielipiteet ovat monien eri tekijöiden summa. (4.)

Yhtenä tekijänä on kysymys siitä, ovatko esimerkiksi homoseksuaaliset ihmiset kykeneviä vanhemmuuteen; onhan homoseksuaalisuutta pidetty Suomessa pitkään sekä rikoksena että psyykkisenä sairautena $(4,6)$. Vanhemman seksuaalisen suuntautumisen on pelätty vaikuttavan perheessä elävän lapsen kehitykseen. Laajan kansainväliseen tutkimustietoon perustuvan kirjallisuuskatsauksen (2) mukaan vanhempien sukupuolella tai seksuaalisella suuntautumisella ei kuitenkaan ole juuri vaikutusta lasten psyykkiseen ja sosiaaliseen hyvinvointiin. Lapsen hyvinvoinnin kannalta oleellista on perheiden toimivuus. Kansainväliseen tutkimustietoon perustuvan kirjallisuuskatsauksen mukaan myös sateenkaariperheiden nuoret toimivat nuoruus- ikään kuuluvilla tavoilla: heidän elämässään on myönteisiä ja kielteisiä asioita niin kuin muillakin nuorilla (7). Suomalaisten sateenkaariperheiden lasten ja nuorten fyysinen, psyykkinen ja sosiaalinen hyvinvointi vastaavat saman ikäisten lasten ja nuorten hyvinvointia. (8.)

Sateenkaariperheet kohtaavat samoja ongelmia kuin muutkin perheet. Erityispiirteenä on kuitenkin se, että osalta sateenkaariperheistä puuttuu sukulaisten tuki. (3.) Syynä voi olla puolisovalinta, joka voi olla ristiriidassa vanhempien arvojen ja odotusten kanssa (9). Syntymäperheen antaman tuen tilalla saattaa olla vertaistuki ja ystävien antama tuki. Sateenkaariperheille luo oman erityispiirteensä myös kulttuuristen mallien puuttuminen. Toisin kuin esimerkiksi romaaniperheillä, sateenkaariperheiltä puuttuu sukupolvia yhdistävä vähemmistökokemus. (10.)

Suomalainen lainsäädäntö korostaa voimakkaasti tasa-arvoa muun muassa terveydenhuoltopalveluissa (11-13). Kuitenkin tutkimusnäytön perustella sukupuoli- ja seksuaalivähemmistöihin kuuluvat henkilöt ovat erilaisessa asemassa terveyden suhteen kuin heteroseksuaaliset henkilöt (14-16). Selittävinä tekijöinä voivat olla näiden henkilöiden erityiset terveysongelmat (17-20), terveydenhuoltohenkilöstön tietämättömyys sukupuoli- ja seksuaalivähemmistön terveysasioista (20-24) ja terveydenhuoltohenkilöstön negatiiviset asenteet, homofobia ja heteroseksuaalinen perusolettamus (25-27). Nämä tekijät koettuina tai oletettuina voivat estää sukupuoli- ja seksuaalivähemmistöön kuuluvia hakeutumasta terveyspalveluihin joko yksilöinä tai sateenkaariperheenä ja näin lisätä heidän haavoittuvuuttaan terveyden suhteen.

Suomessa oli vuonna 2016 rekisteröityjä naispareja, joilla on lapsia yhteensä 658, joista lapsiperheitä (perheessä alaikäinen lapsi) oli 644 (28). Naisparien muodostamista perhemuodoista yleisin on ydinperhe, jolloin lapset on saatu kotiinseminaation tai hedelmöityshoitojen avulla luovutetuilla siittiöillä. Tälle perhemallille tyypillistä on vanhemmuuden jakaminen parisuhteessa elävien naisten kesken. (29.)

Synnyttäjä on Suomessa automaattisesti lapsen biologinen äiti. Biologisesta äidistä tulee useimmiten myös juridinen vanhempi (30). Biologinen äitiys voidaan kuitenkin jakaa tilanteissa, joissa käytetään luovutettua munasolua. Munasolun luovuttanutta naista kutsutaan perinnöl- 
liseksi vanhemmaksi ja synnyttänyttä naista biologiseksi vanhemmaksi. Juridisesta vanhemmuudesta seuraavat elatusvelvollisuus sekä lapsen oikeus perintöön ja tapaamiseen. (31.) Suomessa lapsella voi olla korkeintaan kaksi juridista vanhempaa. Sosiaalinen äiti tarkoittaa äitiä, jolla ei automaattisesti ole juridista tai biologista sidettä lapseen. Sosiaalinen äiti toimii käytännössä lapsen vanhempana, ja perheen sisällä hänet koetaan toiseksi vanhemmista. (30.)

Perheen sisäisellä adoptiolla tarkoitetaan sitä, että perheessä toinen puoliso ottaa ottolapsekseen puolisonsa juridisen lapsen (30). Suomessa on hyväksytty samaa sukupuolta olevien parien perheen sisäinen adoptio vuonna 2009 (32). Avioliittolain muutoksen myötä kaksi samaa sukupuolta olevaa ihmistä voivat solmia avioliiton (33). He voivat myös adoptoida yhdessä perheen ulkopuolelta. Sosiaalisen äidin äitiyden vahvistaminen edellyttää kuitenkin edelleen perheen sisäistä adoptiota. (34.) Tässä tutkimuksessa äidillä tarkoitetaan sekä biologista että sosiaalista äitiä.

Sateenkaariperheen äiteihin kohdistuvaa tutkimusta on tehty vähän Suomessa (35). Kansainvälistä tutkimusta on runsaammin.

\section{TUTKIMUKSEN TARKOITUS, TUTKIMUSKYSYMYS JA TAVOITE}

Tämän integratiivisen kirjallisuuskatsauksen tarkoituksena on kuvata sateenkaariperheiden äitien kokemuksia perheensä elämästä ja siihen yhteydessä olevista tekijöistä aiempien kansainvälisten tutkimusten avulla.

Tutkimuskysymyksenä oli: Millaisia kokemuksia sateenkaariperheiden äideillä on oman perheensä elämästä ja siihen yhteydessä olevista tekijöistä osana yhteiskuntaa?

Tavoitteena on tunnistaa mahdollisia sateenkaariperheiden äitien tuen tarpeita. Katsaus on tarpeen, koska esimerkiksi terveydenhuoltohenkilökunnan on tärkeä tunnistaa erilaiset perheet ja niiden todellisuus sellaisena kuin perheet sen itse kokevat. Lisäksi heillä on oltava riittävästi tietoa erilaisista perheistä kyetäkseen tukemaan näitä perheitä.

\section{AINEISTONKERUU JA ANALYYSI}

Tutkimus toteutettiin integratiivisena katsauksena, koska se mahdollistaa erilaisten tutkimusten mukaan ottamisen katsaukseen ja se sallii myös kvalitatiivisten ja kvantitatiivisten aineistojen käytön samanaikaisesti (36-38). Integratiivinen kirjallisuuskatsaus sopi menetelmäksi hyvin myös siksi, koska sen avulla voidaan tehdä yhteenveto aikaisemmista aihealuetta koskevista tutkimuksista, nostaa esiin ratkaisemattomia asioita ja osoittaa tutkittavana olevan aiheen jatkotutkimuskohteet. (39.)

Integratiivisessa katsauksessa suositellaan kaksivaiheista hakuprosessia, jolloin hakuprosessin ensimmäisessä vaiheessa pyritään määrittämään toisessa vaiheessa käytettävät hakutermit (39). Tämän tutkimuksen ensimmäinen kirjallisuushaku tehtiin Cinahl, Medline ja PsycINFO tietokannoista. Tiedonhaku tuotti yhteensä 495 tutkimusartikkelia. Ennen toista hakukierrosta konsultoitiin informaatikkoa, jonka asiantuntemuksen perusteella valittiin käytettävät hakutermit.

Hakuun sisällytettäviksi valittiin Cinahl, Medline, PsycINFO, Linda, Arto ja Medic -tietokannat. Tämän jälkeen asetettiin tutkimusaineiston mukaanotto- ja poissulkukriteerit, jotta aineisto olisi mahdollisimman hyvin kohdentunut tämän tutkimuksen tarkoituksen mukaisesti. Mukaanottokriteerit olivat seuraavat: 1) tutkimuksen kohdejoukkona oli sateenkaariperheen äiti tai äidit, 2) perheessä oli tai oli ollut yksi tai useampi lapsi, tai biologinen äiti oli tai oli ollut raskaana ja 3) tutkimus oli julkaistu tieteellisessä julkaisussa 4) suomen tai englannin kielellä. Poissulkukriteerit olivat: 1) tutkimus käsitteli perheen ulkopuolista adoptiota, 2) tutkimuksen kohdejoukkona oli lasten hankkimista suunnittelevat pariskunnat tai 3) ne olivat kirjallisuuskatsauksia. Taulukossa yksi kuvataan käytetyt hakusanat ja rajaukset tietokannoittain. (Taulukko 1.)

Aineistoon valittiin yhteensä 49 tutkimusartikkelia kahdeksasta eri maasta. Tutkimusartikkelien valinnasta keskusteltiin tutkimusryhmässä. Tutkimusartikkeleista 33 oli laadullisia, 12 määrällisiä ja neljässä oli käytetty molempia menetelmiä. Tutkimuksista suurin osa oli toteutettu Yhdysvalloissa $(\mathrm{n}=30)$. Loput tutkimuksista oli toteutettu Australiassa $(n=6)$, Englannissa $(n=4)$, Hollannissa $(\mathrm{n}=3)$, Kanadassa $(\mathrm{n}=2)$, Ruotsissa $(n=2)$, Norjassa $(n=1)$ ja Belgiassa $(n=1)$. Aineistona olevien artikkelien laatu arvioitiin käyttäen apuna Joanna Briggs Instituutin (JBI) kehittämiä laadunarviointityökaluja (40). Laadullisille 
Taulukko 1. Integratiivisen kirjallisuuskatsauksen toisen hakukierroksen hakuprofiili.

\begin{tabular}{|c|c|c|c|c|c|}
\hline Tietokanta & Hakutermit ja rajaukset & $\begin{array}{l}\text { Haun } \\
\text { tulokset }\end{array}$ & $\begin{array}{l}\text { Kokotekstinä/abstrakti } \\
\text { tasolla tarkastellut }\end{array}$ & $\begin{array}{l}\text { Koko- } \\
\text { tekstinä } \\
\text { tarkastellut }\end{array}$ & $\begin{array}{l}\text { Aineis- } \\
\text { toon } \\
\text { valitut }\end{array}$ \\
\hline Cinahl & $\begin{array}{l}\text { ("Lesbians" OR } \\
\text { [homosexual"AND female]) AND } \\
\text { ("Child Rearing" OR "Parenting" } \\
\text { OR "Parent-Child Relations" } \\
\text { OR "Mother-Child Relations" } \\
\text { OR "Family Functioning" } \\
\text { OR "Maternal Behavior" OR } \\
\text { "Family" OR "Family Coping" } \\
\text { OR "Family Relations" OR } \\
\text { "Parenthood" OR "Motherhood" } \\
\text { OR "Minority Groups" } \\
\text { Rajaukset: Abstract Available; } \\
\text { English Language; Peer Reviewed; } \\
\text { Research Article; Language: } \\
\text { English }\end{array}$ & 102 & 30 & 15 & 10 \\
\hline Medline & $\begin{array}{l}\text { ("Homosexuality" AND } \\
\text { "Female") AND ("family relations" } \\
\text { OR "parent-child relations" OR } \\
\text { "mother-child relations" OR } \\
\text { "parenting" OR "parents" OR } \\
\text { "mothers" OR "single parent" } \\
\text { OR "single-parent family" OR } \\
\text { "Family" OR "Child Rearing” OR } \\
\text { \{["adolescent" OR "child" OR } \\
\text { "child, preschool" OR "infant"] } \\
\text { NOT [“sexual orientation" OR } \\
\text { "Sexual Behavior"]\}) } \\
\text { Rajaukset: Abstracts, English } \\
\text { Language }\end{array}$ & 478 & 120 & 37 & 15 \\
\hline \multirow[t]{2}{*}{ PsycINFO } & $\begin{array}{l}\text { ("lesbianism") AND ("mothers" } \\
\text { OR "parents" OR "single } \\
\text { mothers" OR "childrearing } \\
\text { practices" OR "family relations" } \\
\text { OR "parenting" OR "mother } \\
\text { child relations" OR "exp parent } \\
\text { child relations" OR "exp parental } \\
\text { attitudes" OR "exp parental } \\
\text { characteristics" OR "parental } \\
\text { role" OR "exp parenting style" } \\
\text { OR "family" OR "exp family } \\
\text { relations" OR "exp living } \\
\text { arrangements") }\end{array}$ & 460 & 242 & 28 & 24 \\
\hline & $\begin{array}{l}\text { Rajaukset: Peer Reviewed Journal, } \\
\text { English Language, Abstracts }\end{array}$ & & & & \\
\hline Arto & $\begin{array}{l}\text { ("sateenkaar?" OR ”lesb?”) AND } \\
\text { ("perhe?" OR “laps?”) }\end{array}$ & 68 & 8 & - & - \\
\hline Linda & $\begin{array}{l}\text { (“lesb?” OR “sateenkaariperh?”) } \\
\text { AND ("perhe?” OR “laps?”) }\end{array}$ & 83 & 12 & - & - \\
\hline Medic & $\begin{array}{l}\text { ("homo"” or "lesb"" or } \\
\text { "sateenkaariperh"”) AND } \\
\text { ("perhe" or "laps"") }\end{array}$ & 24 & 3 & - & - \\
\hline Yht. & & 1215 & 415 & 80 & 49 \\
\hline
\end{tabular}




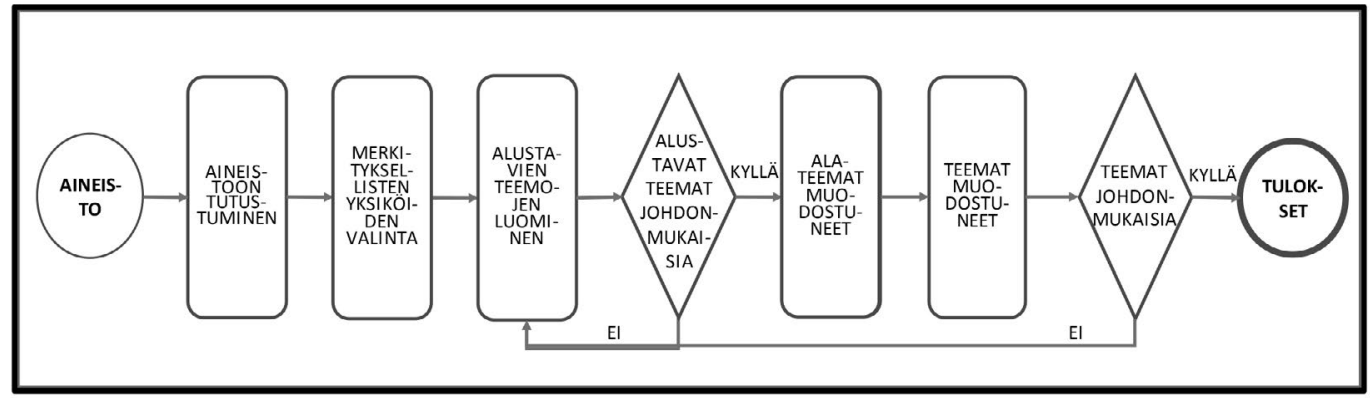

Kuvio 1 . Temaattisen analyysin prosessikuvaus.

tutkimuksille apuna käytettiin QARI-kriittisen arvioinnin työkalua ja määrällisille tutkimuksille apuna käytettiin MAStARI-kriittisen arvioinnin työkalua. Tutkimukset, joissa oli käytetty sekä laadullista että määrällistä metodia, arvioitiin käyttäen kumpaakin työkalua. Laadulliset tutkimukset saivat arvioinnissa pisteitä välillä 6-10 maksimipistemäärän ollessa 10 ja määrälliset vastaavasti 5-8 pistettä maksimimäärän ollessa 9.

Tutkimuksen aineisto analysoitiin temaattisella analyysilla, koska se sallii aineiston kokonaisvaltaisen lähestymisen tutkimuskysymykseen vastaavien teemojen avulla sekä tutkijan tulkinnan teemojen ryhmittelyssä (41). Analyysissa yhdistettiin määrällisten ja laadullisten tutkimusten tulokset siten, että määrällisten tutkimusten numeeriset tulokset on sanoitettu eli muunnettu tekstimuotoon. Ensimmäiseksi analysoitavaan aineistoon tutustuttiin lukemalla se useaan kertaan. Tämän jälkeen aineistosta etsittiin merkitykselliset tekstiyksiköt, jotka vastaavat tutkimuskysymykseen ja niihin liitettiin artikkelin identifioiva numerotunniste. Merkityksellisistä tekstiyksiköistä etsittiin yhteneväisyyksiä ja samankaltaiset yksiköt ryhmiteltiin alustaviksi teemoiksi. Alustavia teemoja tarkasteltiin yhdessä etsien alustavista teemoista yhdistäviä tekijöitä. Analyysiprosessissa palattiin välillä takaisin alkuperäiseen aineistoon, kunnes alustavat teemat voitiin hyväksyä loogisesti ryhmittyviksi johdonmukaisiksi alateemoiksi. Muotoutuneet alateemat yhdisteltiin edelleen teemoiksi, joiden johdonmukaisuus arvioitiin ja tarvittaessa palattiin jälleen takaisin alkuperäiseen aineistoon. Teemojen valinnan jälkeen palattiin vielä takaisin alkuperäiseen aineistoon ja tarkastettiin saadut teemat sekä suhteessa alkuperäiseen aineistoon että suhteessa toisiinsa. (42-43.)

\section{TULOKSET}

Selviytyminen sateenkaariperheenä kuvaa sitä, miten äidit yrittävät selviytyä sateenkaariperheenä huolimatta siitä, että he kokivat elävänsä perinteisestä heteroydinperheestä poikkeavassa perheessä ja vähemmistöasemasta aiheutuvien ennakkokäsitysten kanssa. (Kuvio 2)

\section{ELÄMINEN PERINTEISESTÄ HETEROYDINPERHEESTÄ POIKKEAVASSA PERHEESSÄ}

Sateenkaariperheiden äidit kuvasivat perhe-elämäänsä kahdesta näkökulmasta: äitien keskinäisten roolien etsimisen ja tasapainon vahvistamisen näkökulmasta sekä elämistä sosiaalisena äitinä ja vanhempana, jota ei tunnusteta eikä tunnisteta (Kuvio 3).

\section{Äitien keskinäisten roolien etsiminen ja tasapainon vahvistaminen}

Perheissä äitien roolit jakautuivat usein feminiinisesti ja maskuliinisesti (44-45). Biologisten äitien roolit korostuivat biologisen siteen kautta (4647). Sen puuttuminen ei kuitenkaan vaikuttanut vanhemmuuden laatuun (48). Äidit tekivät työtä saavuttaakseen tasapuolisuuden suhteessa lapsiin $(45,47)$ järjestämällä aikaa lapsille työjärjestelyin (49), jakamalla kotitöitä (49-51), vahvistamalla sosiaalisten äitien roolia (52) ja perheen sisäisellä adoptiolla (47). Biologiset äidit käyttivät enemmän aikaa lapsenhoitoon $(47,50)$ ja sosiaaliset äidit työskentelivät enemmän kodin ulkopuolella (50). Toisaalta osassa tutkimuksia tässä ei ollut merkittävää eroa (53). Äidit kokivat olevansa tasavertaisia vastuussa ja toisen tilanteen ymmärryksessä (51).

Äitien kokemuksen mukaan perheissä koettiin mustasukkaisuutta lapsesta $(49,54-55)$. Mustasukkaisuutta aiheutti molempien naisten halu 


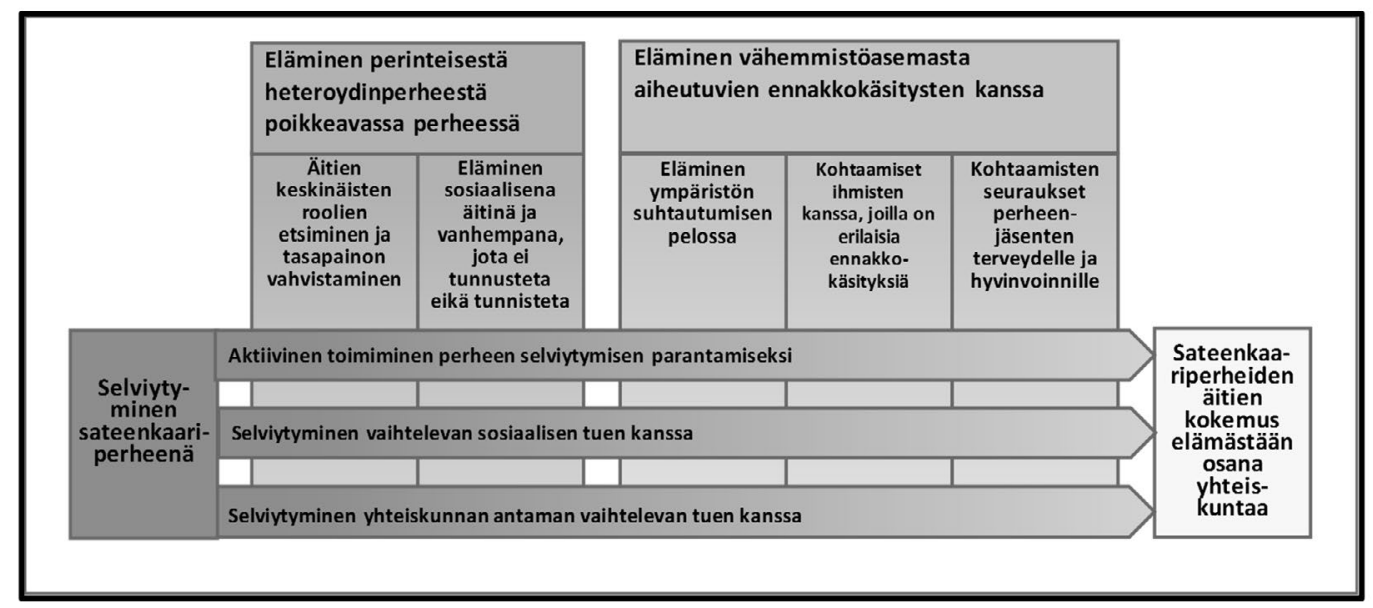

Kuvio 2. Sateenkaariperheen äitien kokemukset perheensä elämästä osana yhteiskuntaa aiempien kansainvälisten tutkimusten $(\mathrm{n}=49)$ mukaan.

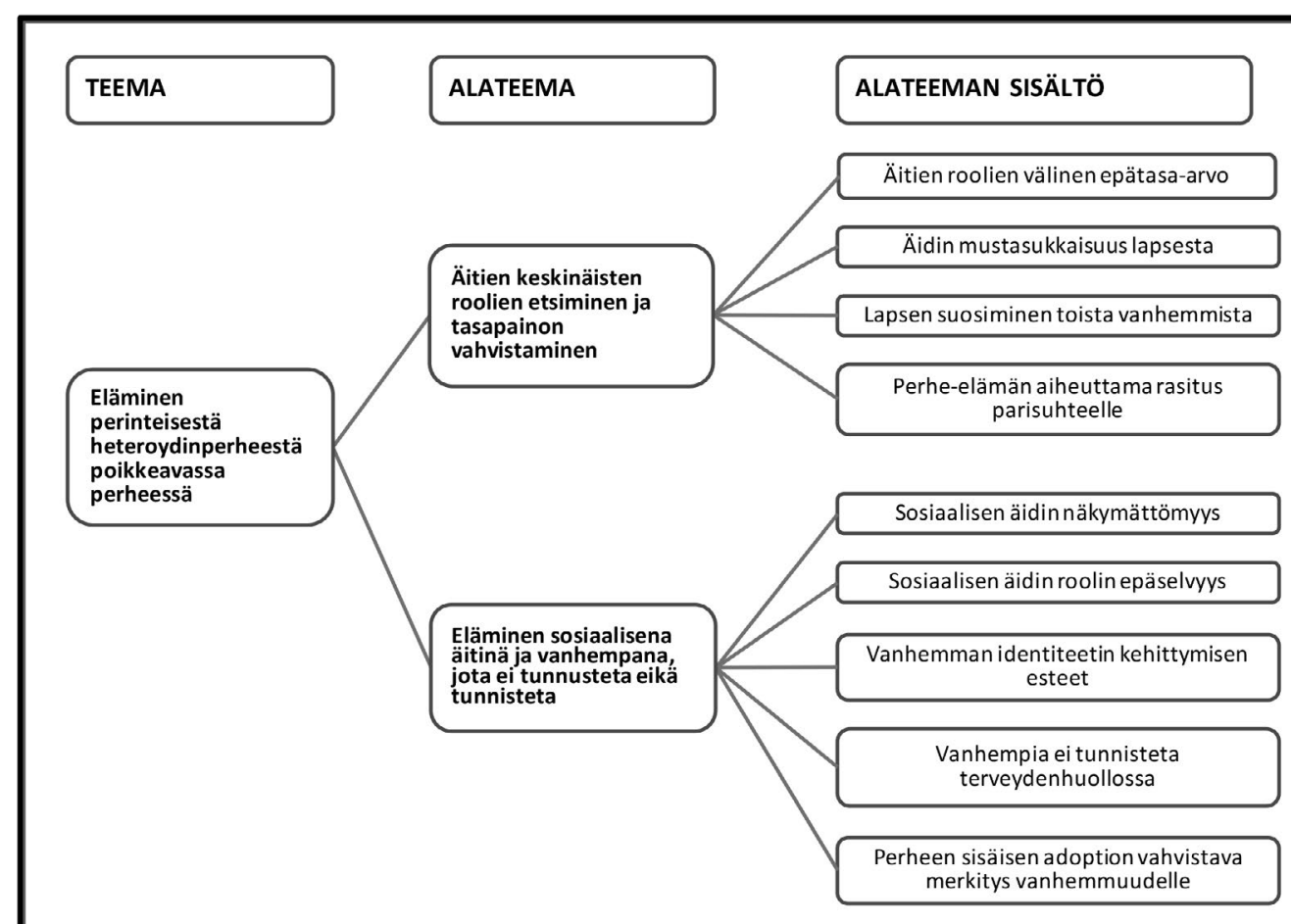

Kuvio 3. Sateenkaariperheiden äitien kokemus elämisestä perinteisestä heteroydinperheestä poikkeavassa perheessä aiempien kansainvälisten tutkimusten $(\mathrm{n}=49)$ mukaan.

olla raskaana, biologisten äitien ensisijainen suhde lapseen, imetys, hedelmättömyys (49) ja toisen äidin suosiminen lapsen taholta (45). Mustasukkaisuutta vähensi selkeä työnjako, roolien jakaminen perinteisesti, imettämisen epäonnistuminen ja adoptiovanhemmuus (49).
Lapset suosivat biologisia äitejä hoivan tarpeessa (45), syöttämisessä ja iltarutiineissa (49). Sosiaalisia äitejä suosittiin peleissä ja leikeissä (45). Sosiaalisilla äideillä oli perheessä turvattomuuden tunnetta (49). Tunne saattoi esiintyä, vaikka lapset kohtelivat heitä molempia äiteinä (56). 


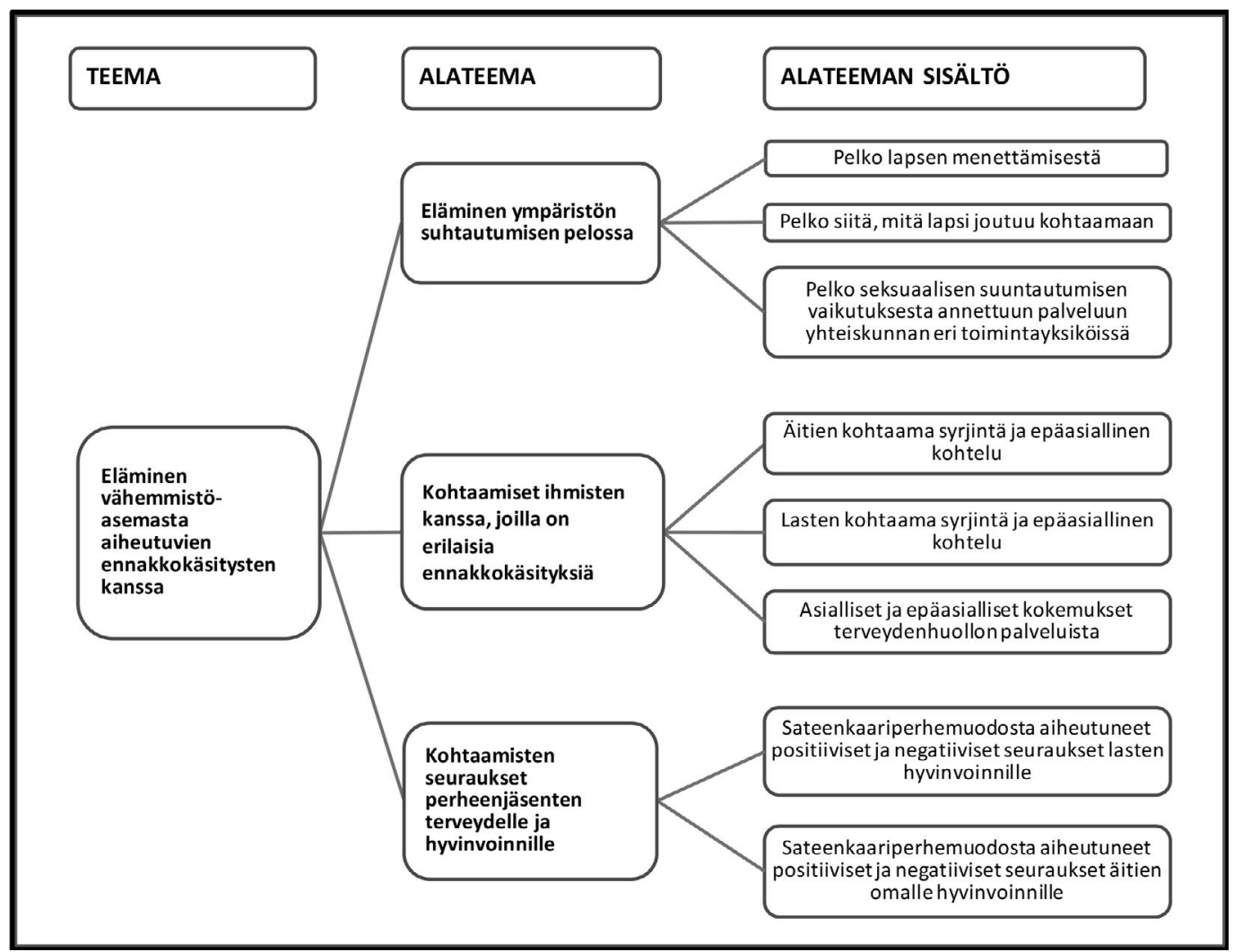

Kuvio 4. Sateenkaariperheiden äitien kokemus elämisestä vähemmistöasemasta aiheutuvien ennakkokäsitysten kanssa aiempien kansainvälisten tutkimusten $(\mathrm{n}=49)$ mukaan.

Parisuhteessaan äidit raportoivat tukevaa, joustavaa ja tyydyttävää suhdetta, joka tarjosi vahvan perustan hyvinvoinnille (57). Biologiset äidit olivat heteroperheiden äitejä tyytyväisempiä partneriinsa (53). Parisuhteen virallistamisen koettiin voimistavan tunnetta perheestä, turvallisuudesta ja pysyvyydestä (58). Tutkimuksissa raportoitiin myös negatiivisista muutoksista parisuhteessa lapsen syntymän jälkeen (59). Jotta lapselle kehittyisi tasapuolinen side kumpaankin vanhempaan, äidit sopivat työnjaosta ja järjestivät sosiaaliselle äidille aikaa lapsen kanssa. Tämä aiheutti parisuhteelle kuormitusta (60). Biologiset äidit, jotka tekivät enemmän kotitöitä, kokivat rasittuvansa enemmän lasten takia, kuin sosiaaliset äidit. (53).

\section{Eläminen sosiaalisena äitinä ja vanhempana,}

jota ei tunnusteta eikä tunnisteta

Sosiaaliset äidit kokivat olevansa näkymättömiä yhteiskunnassa (51). Äitien parisuhteelta saattoi puuttua tasa-arvoiset ja lailliset oikeudet (61). Sosiaaliset äidit eivät voineet allekirjoittaa laillisia lapseen liittyviä dokumentteja ilman todistusta biologisilta äideiltä $(56,62)$. Sosiaaliset äidit kokivat, että heitä ei aina hyväksytty (60) tai heidät jätettiin ulkopuolelle (52).

Sosiaalisten äitien roolia kuvaavan termin puuttuminen $(44,46,62-63)$ ja roolin puutteellinen määrittely yhteiskunnan eri tasoilla koettiin vaikeaksi $(45,51)$. Äidit olivat kokeneet roolinsa epäselväksi suhteessa toisiin vanhempiin (62) ja biologisiin isiin (46,64-65). Myös sosiaalisten äitien vanhemmilla oli vaikeuksia ymmärtää omaa rooliaan $(46,60)$.

Sateenkaariperheen vanhempien identiteetin kehittyminen vaikeutui laillisten oikeuksien puuttuessa (62). Sosiaaliset äidit kokivat olevansa puutteellisia vanhempia, koska eivät voineet toimia juridisina vanhempina (66). Oikeuksien puute aiheutti ongelmia esimerkiksi erotilanteessa (46), jolloin sosiaaliset äidit joutuivat usein eril- 
leen lapsesta (51). Äidit kokivat painetta todistaa kykynsä vanhemmuuteen $(53,63,67)$ jopa omille vanhemmilleen (46).

Sosiaalisia äitejä ei tunnustettu juridisina vanhempina terveydenhuollossa. Esimerkiksi hoitoon liittyvät lomakkeet oli tarkoitettu heteroperheille. (55,68-69). Terveydenhuoltohenkilöstöllä oli taipumus huomioida vain toinen vanhemmista (70). Sosiaalisia äitejä ei nähty lähiomaisina (71). Synnytysvalmennuksen aikana sosiaalisia äitejä saatettiin kutsua isiksi $(69,71-$ 72) tai jopa aviomiehiksi (72). Heteroperheitä kutsuttiin normaaleiksi perheiksi (71).

Perheen sisäinen adoptio koettiin tärkeäksi ja vapauttavaksi (56), mutta hitaaksi (60), kalliiksi ja raskaaksi prosessiksi (59). Se takasi lapselle oikeuden perintöön, varmisti äiti-lapsi suhteen jatkuvuuden (56) ja juridisesti jaetun huoltajuuden lapsesta erotilanteessa (54). Adoptio koettiin tärkeäksi osaksi vanhemmaksi tulemista (55). Sosiaaliset äidit kokivat tärkeäksi virallisen oikeuden äitiyteen ja vanhemmuuteen (73).

\section{ELÄMINEN VÄHEMMISTÖASEMASTA AIHEUTUVIEN ENNAKKOKÄSITYSTEN KANSSA}

Äitien kokemukset elämisestä vähemmistöasemasta aiheutuvien ennakkokäsitysten kanssa olivat kolmenlaisia (Kuvio 4): ympäristön suhtautumiseen kohdistuvat pelot, kohtaamiset ihmisten kanssa, joilla oli ennakkokäsityksiä sekä kokemus siitä, että heidän kohtaamansa asiat olivat aiheuttaneet seurauksia perheenjäsenten terveydelle ja hyvinvoinnille.

\section{Eläminen ympäristön suhtautumisen pelossa}

Äidit, jotka olivat saaneet lapsensa ennen seksuaalisen suuntautumisensa julki tuomista, olivat enemmän peloissaan kuin äidit, jotka saivat lapsensa sen jälkeen (74). Sosiaalisten äitien pelättiin menettävän oikeutensa lasten huoltajuuteen $(52,56)$. Lapsille saatettiin valita tuntemattomat luovuttajat, jotta biologiset isät eivät voi vaatia lapsia itselleen (52).

Äidit miettivät lapsen hyvinvointia valitessaan tunnetun ja tuntemattoman luovuttajan välillä. Valinnan seurauksista oltiin huolissaan. (75.) Äidit pelkäsivät lapsiensa joutuvan vanhempien seksuaalisesta suuntautumisesta johtuvan kiusaamisen ja nimittelyn kohteeksi $(51,76)$ erityisesti koulutoverien ja heidän vanhempien- sa taholta (77). Äidit olivat huolissaan lapsiin kohdistuvista ennakkoluuloista ja syrjinnästä $(51,61,65)$. Lisäksi pelättiin vanhempiin tai isään kohdistuvien kysymysten vaikutuksia $(54,60,78)$.

Äidit pelkäsivät ennakkoluuloja, salassapitovelvollisuuden rikkomista (79) ja vanhemmuuden kyvyn kyseenalaistamista (64) sosiaali- ja terveydenhuollon toimintayksiköissä. Äitiyshuollon henkilöstön reaktiot seksuaaliseen suuntautumiseen huolettivat (69). Lisäksi äidit pelkäsivät, että terveydenhuollossa kieltäydytään antamasta hoitoa (57), tai että seksuaalinen suuntautuminen vaikuttaa annettuun hoitoon $(55,64,79)$. Äidit pelkäsivät lasten huostaanottoa, työn menettämistä, epäasiallista kohtelua sosiaali- ja terveydenhuollon ammattilaisilta (80-82), tai että lasten käyttäytymisen ongelmien ajatellaan johtuvan äitien seksuaalisesta suuntautumisesta (76).

\section{Kohtaamiset ihmisten kanssa, joilla on erilaisia ennakkokäsityksiä}

Äidit olivat kohdanneet sosiaalisessa kanssakäymisessään syrjintää, ennakkoluuloja, kommentteja (78), torjuntaa (51), nimittelyä, häirintää (76), kiusallisia kysymyksiä, juoruilua (67), skeptisyyttä (52), fyysistä väkivaltaa (76), uhkailua huoltajuuden menettämisestä (74), välttelyä (51), homofobiaa ja seksismiä (59). Äidit olivat kokeneet vihamielisyyttä koulussa, postissa, työpaikalla ja päivähoidossa (65). Lisäksi he olivat kokeneet leimaavaa ja vähättelevää reagointia sosiaali- ja terveydenhuollon ammattilaisten taholta (81), mutta myös esimerkiksi vakuutusyhtiöiden (70) ja lehdistön tahoilta (52). Syrjäseudulla asuvat äidit raportoivat enemmän syrjintää kuin kaupungissa asuvat (63).

Sateenkaariperheiden lapsille oli saatettu sanoa vanhempien seksuaalisen identiteetin olevan väärä ja moraaliton, josta ei ole hyvä puhua avoimesti. Tämä oli ristiriidassa vanhempien oman kertomuksen kanssa. (83.) Teini-ikäiset lapset olivat ilmaisseet pelkonsa kertoa avoimesti kavereilleen vanhempiensa seksuaalisesta suuntautumisesta (51). Koulussa oli kerrottu, että "homot ja lesbot eivät pääse taivaaseen”. Tämä oli aiheuttanut ahdistuneisuutta ja pelkoa. (65.) Osalla sateenkaariperheen vanhemmista oli kokemus koulun viivyttelystä kiusaamiseen puuttumisessa, opettajien homofobisesta asenteesta sekä lastensa kiusaamisesta ja nimittelystä. (51.) Lasten 
luokkatoverit olivat kyseenalaistaneet perheen kaksi äitiä (58).

Äitien asialliset kokemukset terveydenhuollon palveluissa muodostuivat hyväksymisestä normaaleina, kunnioituksesta, miellyttävyydestä, turvallisuudesta ja molempien äitien huomioimisesta. $(55,68,79)$. Äidit mainitsivat kätilöiden herkkyydestä (84) ja kätilöihin oltiin tyytyväisiä (72). Positiivisen kokemuksen antoi se, jos kätilö yllättyneisyydestään huolimatta suhtautui ystävällisesti, ja hän otti sosiaalisen äidin huomioon alusta alkaen (69). Suurin osa vanhemmista oli tyytyväisiä omalääkäriltä saamaansa hoitoon (64).

Epäasialliset kokemukset terveydenhuollon palveluissa sisälsivät syrjintää, tuomitsemista, homofobista asennetta, ylimääräisiä kysymyksiä perheestä (64), hetero-oletusta (68) tai heteroseksististä suhtautumista $(59,70)$. Terveydenhuoltohenkilöstö saattoi kieltäytyä antamasta hoitoa tai neuvontaa $(79,84-85)$. Epäasiallisesta kohtelusta ei uskallettu valittaa (68).

Äidit olivat toivoneet terveydenhuollon palveluissa parisuhteesta puhumisen olevan turvallista, mutta käytännössä näin ei ollut (68). Äidit kokivat, että synnytysvalmennus oli suunnattu vain heteroille. Suhtautuminen äitejä kohtaan saattoi olla avoimen kielteistä tai heidän seksuaalinen suuntautumisensa saatettiin ohittaa kokonaan. (79.) Äidit olisivat toivoneet, että heiltä olisi kysytty elävätkö he miehen vai naisen kanssa (55). Toisaalta tärkeäksi koettiin se, että keskityttiin raskauteen ja tulevaan vanhemmuuteen, ei äitien seksuaaliseen suuntautumiseen (69).

\section{Kohtaamisten seuraukset perheenjäsenten terveydelle ja hyvinvoinnille}

Perheen suunnittelu koettiin tärkeäksi, uskottiin että lapset kokisivat olevansa haluttuja, rakastettuja ja kunnioitettuja (51). Lapset pärjäsivät paremmin, kun perhetilanne oli stabiili ja molemmat äidit toimivat vanhempina $(66,80)$. Äidit olivat ylpeitä ja kokivat suurimmaksi vahvuudekseen onnelliset lapset (51). Äitien mukaan heidän lapsillaan oli erinomaiset sosiaaliset taidot (66). Naapuruston hyväksyvä asenne sekä työpaikan ja perheen tuki ja rakkaus vähensivät adoption valinneiden äitien masennus- ja ahdistusoireita adoptiohetkellä (86).

Äidit, jotka kokivat vähemmistöasemansa vuoksi torjumista, tai joilla oli enemmän psyyk- kisiä häiriöitä, raportoivat lapsillaan enemmän käytöshäiriöitä $(67,87)$. Lapset, jotka olivat kohdanneet äitien seksuaalisen suuntautumisen vuoksi leimaavaa käytöstä, osoittivat psyykkisen stressin oireita (54). Tunnetun luovuttajan valinneet äidit kokivat lapsillaan olevan enemmän sosiaalisia ongelmia, tarkkaavaisuushäiriöitä ja somaattisia ongelmia (88). Keski-ikäisinä äidit kokivat olevansa varmempia vanhemmuudessaan suhteessa ennakkoluuloihin ja syrjintään (78). Lasten itsetunto oli matalampi, jos biologiset isät eivät hyväksyneet äitien seksuaalista suuntautumista (66). Syrjäseudun lapset eivät puhuneet perheestään yhtä avoimesti koulutovereille tai naapureille, kuin lapset kaupungeissa (51).

Äidit kokivat joutuneensa luopumaan lesboystävistään saadessaan lapsia $(65,76)$ ja omien perheiden sekä heteroperheiden kanssa oltiin yhä enemmän tekemisissä. Tämä ei ollut helppoa ja sillä oli vaikutusta esimerkiksi omaan identiteettiin. Sukulaisille raskaus oli ensin sokki, joka muuttui myöhemmin iloksi. Toisilla tätä muutosta ei tapahtunut, vaan raskaus koettiin häpeällisenä ja se vaikutti sukulaissuhteisiin. (65.)

Äideillä esiintyi ahdistus- ja masennusoireita sekä stressiä. Näitä oireita aiheuttivat muun muassa perheen juridisen tunnustamisen puute (59-60,65,89), sisäistetty homofobia ja asuminen alueella, jossa oli epäedullinen oikeudellinen ilmasto (86). Lisäksi stressiä aiheuttivat epävarmuus oman perhemuodon esilletuomisesta koulussa. Väärinymmärrys ja näkymättömyys koulumaailmassa aiheuttivat sosiaalisille äideille mielipahaa ja turhautumista. (77.) Lisäksi tuen puute tai kielteinen suhtautuminen läheisiltä äidiksi tullessa lisäsi stressiä (60).

Terveydenhuoltohenkilökunnan opastaminen esimerkiksi sukupuolivähemmistöistä koettiin raskaaksi silloin kun itse oli haavoittuva ja tuen tarpeessa (70). Äidit kokivat joutuneensa käyttämään paljon aikaa yrittäessään selviytyä vaikeuksien läpi. Yksi äiti epäili edellä kuvatun vaikeuttaneen synnytyksen jälkeistä masennusta. (73.) Sen sijaan äidit, jotka kokivat oman seksuaalisuutensa positiivisena ja kertoivat siitä avoimesti, olivat myös avoimempia kertomaan mahdollisesta perheväkivallasta perheelle, ystäville, terveydenhuoltohenkilöstölle tai poliisille (81). 


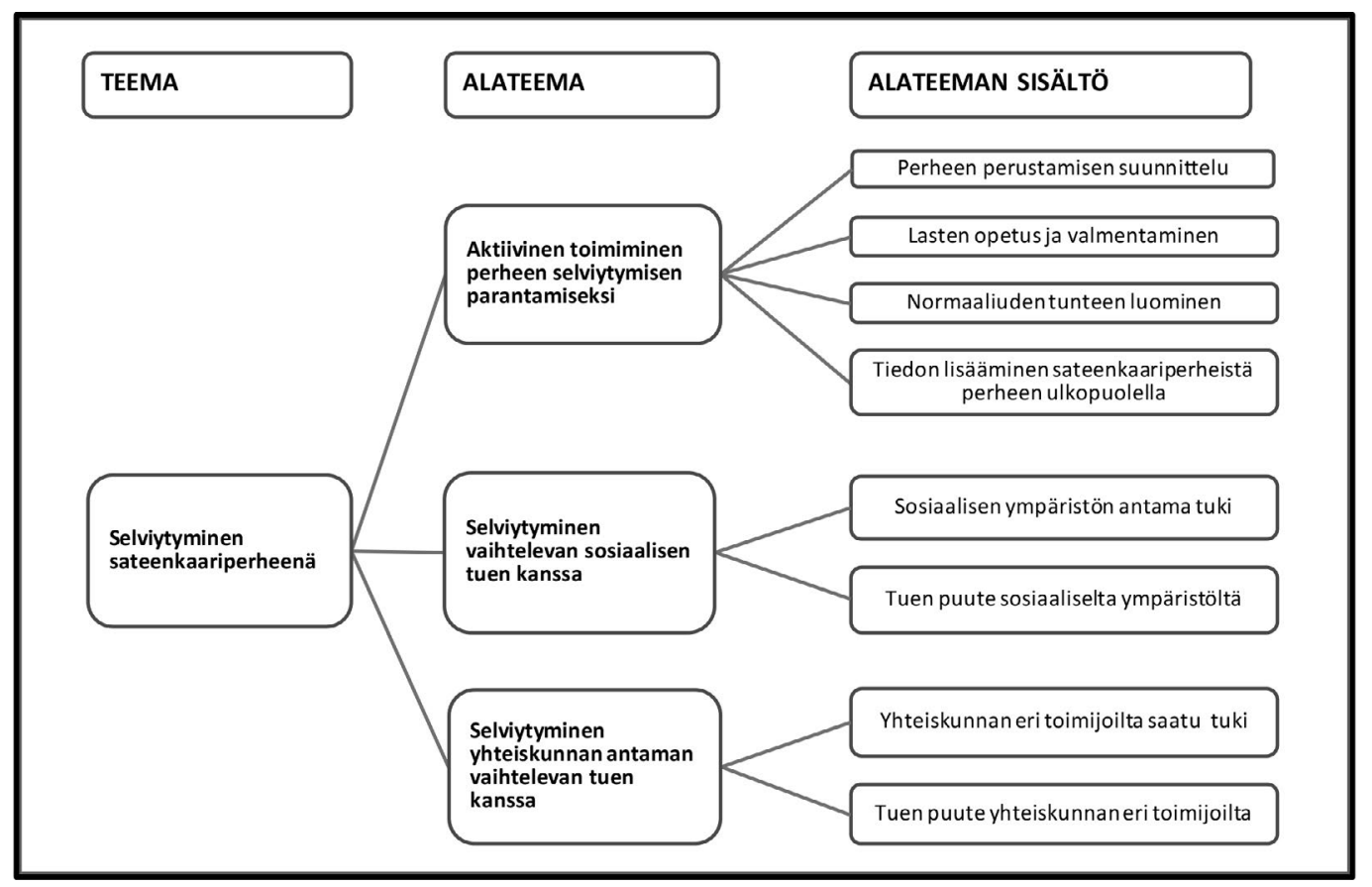

Kuvio 5. Sateenkaariperheiden äitien kokemus selviytymisestä sateenkaariperheenä aiempien kansainvälisten tutkimusten $(\mathrm{n}=49)$ mukaan.

\section{SELVIYTYMINEN SATEENKAARIPERHEENÄ}

Äidit pyrkivät toimimaan aktiivisesti perheensä selviytymisen parantamiseksi. Sosiaaliselta ympäristöltä ja yhteiskunnan taholta saatu tuki oli vaihtelevaa (Kuvio 5).

\section{Aktiivinen toimiminen perheen selviytymisen parantamiseksi}

Raskaus oli tarkkaan harkittu ja suunniteltu $(52,71,85)$. Se oli myös vaikea päätös $(61)$ sekä kallis ja pitkä prosessi $(46,61)$. Halu saada lapsia koettiin osana naisena olemisen identiteettiä, ei osana seksuaalista suuntautumista (52). Sukusolujen luovuttajien valinta oli tarkoin harkittua $(52,75)$. Äidit miettivät luovuttajien valinnan vaikutuksia ja biologisten isien osallistumista lasten elämään (85). Äidit pyrkivät valitsemaan terveyspalveluiden tuottajia, jotka antaisivat tukea ja suhtautuisivat ystävällisesti (71).

Lasten kanssa keskusteltiin perheen identiteetistä (58). Äidit halusivat lastensa oppivan, että sateenkaariperhe on normaali perhe, jonka osa ihmisistä hyväksyy ja osa ei. Lapsille haluttiin opettaa kriittistä suhtautumista muiden mielipiteisiin ja sitä, että erilaisuudessa ei ole mitään väärää (83.) Äidit kokivat, että heidän pitää opettaa lapsilleen selviytymiskeinoja, jotta lapset voivat kehittää omat keinonsa selviytyä (75-76).

Äideillä oli tarve luoda normaaliuden tunne, jotta he voivat antaa lapsilleen positiivisen tunteen perheestä (58). Normaalius tarkoitti sitä, että tehdään samoja asioita kuin muut perheet. Normaaliuden tunnetta lisättiin tapaamalla muita sateenkaariperheitä $(58,90)$, lukemalla aihetta käsitteleviä kirjoja (58), adoption ja hääseremonian avulla (46) sekä käyttämällä yhteistä sukunimeä merkkinä perheestä $(90)$.

Huomattuaan terveydenhuoltohenkilöstön tiedon tarpeen (79), äidit kokivat velvollisuudekseen kertoa heille sateenkaariperheiden todellisuudesta (69-70,78). Äidit kouluttivat myös lastenhoitoa tarjoavia yksiköitä (78) ja koulun henkilökuntaa (54). Yhteistyöhön koulun kanssa oltiinkin tyytyväisiä, tosin se oli edellyttänyt äideiltä paljon työtä (77).

\section{Selviytyminen vaihtelevan sosiaalisen tuen kanssa}

Läheisten tuki koettiin tärkeäksi äideiksi tultaessa (60). Lapsille oli tärkeää kokea, että sukulaiset hyväksyvät äitien seksuaalisen suuntautumisen (83). Yhteisön hyväksyntä sekä perheystävien tuki olivat positiivinen yllätys (78). Osa sateenkaa- 
riperheiden äideistä koki saavansa lapsettomia naisia enemmän tukea sukulaisiltaan (91). Osa puolestaan koki saaneensa enemmän tukea ystäviltä kuin perheenjäseniltä. Homofobiaa tai heteroseksisimiä terveydenhuoltohenkilöstön taholta kokeneet raportoivat saaneensa paljon tukea perheeltä ja ystäviltä. (59.) Eniten tukea saatiin omalta kumppanilta äidiksi tullessa (60). Lapsen menetyksen yhteydessä saatu vahva sosiaalinen tuki helpotti tilannetta (92). Yllättäen suurin tuki tuli heteroseksuaalisilta keskenmenon kokeneilta vanhemmilta, ei lesboyhteisöstä (85).

Kaikissa tilanteissa etenkään sosiaaliset äidit eivät kokeneet saavansa sosiaalista tukea (52). Myös lapset oli jätetty tuen ulkopuolelle (51). Lapsensa menettäneet äidit kokivat itsensä ryhmiin kuulumattomiksi, ja seksuaalisen suuntautumisen vaikuttaneen saamaansa sosiaaliseen tukeen. Osa äideistä keskeytti tukiryhmissä käymisen epämukavuuden tunteen tai arvostelun takia. (92.) Sosiaalisen äidin menetykset jäivät näkymättömiksi erotilanteessa ja kumppanin tai lapsen kuoleman kohdatessa $(51,85)$. Äidit olivat hämmästyneitä sateenkaariyhteisön tuen vähäisyydestä (60-61). Myös median negatiivinen asenne koettiin vaikeaksi hyväksyä (51).

\section{Selviytyminen yhteiskunnan antaman vaihtelevan tuen kanssa}

Sateenkaariperheiden ja heteroperheiden äidit eivät eronneet toisistaan suhteessa yhteiskunnan antamaan informaatioon ja tukeen (53). Kokemukset terveydenhuoltohenkilöstöä kohtaan olivat positiivisia silloin, kun se ei arvostellut tai olettanut mitään, äitien homoseksuaalisuus hyväksyttiin luonnollisena asiana (55) ja heitä kohdeltiin tasavertaisina (70). Suurin osa oli tyytyväisiä synnytykseen ja neuvolapalveluun (79). Keskenmenotilanteissa kohtelu sairaalassa oli pääsääntöisesti huomaavaista ja tukea antavaa (85). Osalla perheväkivaltaa kohdanneista äideistä oli positiivinen kokemus avun saamisesta (81).

Osa äideistä koki hoitohenkilökunnan taholta empatian ja potilaskeskeisyyden puutetta (92). Heillä oli kokemus, että sosiaalista äitiä ei otettu huomioon $(70,72)$. Eräs äiti koki kätilön pitäneen äidin tilannetta uskomattomana ja häntä ”iljettävänä” (69). Epämiellyttävältä tuntui, jos neuvolassa sivuutettiin raskauden alkaminen hedelmöityshoidon avulla tai kätilöt eivät tunnustaneet ilmeistä epävarmuuttaan (57). Seksuaali- sen suuntautumisen kertomatta jättäminen esti luottamuksellisen suhteen syntymisen terveydenhoitajan kanssa, jolloin äiti jäi ilman tarvittavaa tukea (79). Suurin kritiikki kohdistui vanhempien ohjaukseen synnytyksessä ja neuvolapalveluissa. Äidit kokivat ohjauksen olevan suunniteltu tilainteisiin, joissa on äiti ja isä (55). Kukaan äideistä ei ollut saanut riittävästi valmennusta synnytykseen tai vanhemmuuteen äitiyshuollon yksiköstä (69).

\section{POHDINTA}

\section{LUOTETTAVUUS JA KATSAUKSEN RAJOITUKSET}

Tutkimuksen tarkoituksena oli kuvata sateenkaariperheiden äitien kokemuksia perheensä elämästä osana yhteiskuntaa aikaisempia aihealueen tutkimuksia analysoimalla. Menetelmäksi valittiin integratiivinen kirjallisuuskatsaus. Näin tutkimuskysymys saatettiin asettaa väljästi ja tutkittavaa aineistoa valittaessa oli mahdollista hyödyntää eri metodein toteutettuja alkuperäistutkimuksia. (37-38.) Toisaalta tutkimuskysymys rajasi aiheen selkeästi kohdejoukon ja ilmiön osalta. Aineiston mukaanotto- ja poissulkukriteerit oli määritelty tarkasti ja näin oli mahdollista valita olennaiset tutkimukset aineistosta. (39.) Aineiston keruu tehtiin systemaattisesti kansallisista ja kansainvälisistä tietokannoista hyödyntäen informaatikon asiantuntemusta (taulukko 1).

Katsauksen heikkoutena voidaan pitää sitä, että katsaukseen valikoituneiden tutkimusten lähdeluetteloista ei poimittu aineistoa manuaalisella haulla. Artikkelien laatua arvioitiin (37-38) käyttäen apuna JBI:n laadunarvioinnin työkaluja (40). Temaattinen analyysi valittiin analyysimenetelmäksi sen joustavuuden vuoksi. Se soveltuu integratiivisen katsauksen analyysimenetelmäksi, sillä sen avulla voidaan tunnistaa toistuvia, kokemuksia ja ilmiöitä kuvaavia teemoja moniulotteisesta, erilaisia aineistoja sisältävästä kirjallisuudesta (93-94). Analyysivaiheen luotettavuutta lisättiin kuvaamalla analyysiprosessi mahdollisimman läpinäkyvästi (37). Analyysivaiheista ja tehdyistä ratkaisuista keskusteltiin säännöllisesti tutkimusryhmässä.

Koska suomalaista mukaanottokriteerit täyttävää tutkimusta aiheesta ei ollut saatavilla, tutkimukseen valikoitui ainoastaan muissa maissa kuin Suomessa toteutettuja tutkimuksia. Tämä 
aiheuttaa ongelmia tulosten yleistettävyydelle, koska tutkimuksen aihe ja katsauksen tulokset ovat sidoksissa esimerkiksi kunkin maan erilaisiin kulttuureihin ja osakulttuureihin, kulttuurisiin normeihin ja ihanteisiin sekä sosiaali- ja terveyspalvelujärjestelmiin. Myös suhtautuminen homoseksuaalisuuteen ja sen myötä myös esimerkiksi sateenkaariperheisiin vaihtelee historiallisesti ja kulttuurisesti (95-96).

\section{YHTEENVETO KESKEISISTÄ TUTKIMUSTULOKSISTA}

Tutkimuksen ydintulokset osoittivat sateenkaariperheiden äitien elävän perinteisestä heteroydinperheestä poikkeavassa perheessä ja siten myös vähemmistöasemasta johtuvien ennakkokäsitysten kanssa. Äidit pyrkivät toimimaan aktiivisesti perheensä selviytymisen parantamiseksi. (Kuvio 2.)

Perinteisestä heteroydinperheestä poikkeavassa perheessä elämiseen liittyen äidit joutuivat etsimään äitien keskinäistä roolia ja pyrkimään tasapainon vahvistamiseen. Biologisten äitien rooli korostui biologisen siteen kautta. Vanhemmuuden myötä äidit saattoivat kohdata perheen sisällä mustasukkaisuutta lapsesta ja toisen vanhemman suosimista lapsen taholta. Äitien rooleissa pyrittiin kuitenkin tasapainoisuuteen. Vanhemmuuden laadussa ei ollut eroa perheen sisällä. Kodin ulkopuolella työskentelyyn käytetyn ajan ero äitien välillä näytti vaihtelevan sen mukaan, missä maassa tutkimus oli suoritettu. Tehtävien jako tasapuolisesti aiheutti parisuhteelle rasitusta ja äidit raportoivatkin negatiivisia muutoksia parisuhteessa lapsen syntymän jälkeen.

Sosiaalisten äitien roolia ei aina hyväksytty ja heidät jätettiin ulkopuoliseksi perheen ulkopuolella. Sosiaalisen äidin termin puuttuminen ja roolin puutteellinen määrittely olivat merkittäviä tasa-arvoa vähentäviä tekijöitä. Puutteelliset lakisääteiset oikeudet koettiin haittana ja syrjintänä. Sosiaaliset äidit joutuivat vakuuttelemaan vanhemmuutensa laatua muille ihmisille. Perheen sisäinen adoptio oli vapauttava, joskin hidas ja raskas prosessi.

Vähemmistöasemaan liittyvien ennakkokäsitysten kanssa eläminen merkitsi pelkoja ympäristön suhtautumisesta, ennakkokäsitysten kanssa elävien ihmisten kohtaamista sekä äitien kohtaamien vaikeuksien aiheuttamia seurauksia perheenjäsenille. Äidit pelkäsivät menettävänsä lapsensa. Äitien pelot liittyivät myös siihen, mitä lapset joutuvat kokemaan ja miten vanhempien seksuaalinen suuntautuminen vaikuttaa palveluiden laatuun esimerkiksi terveydenhuollossa. Pelättiin kiusaamista ja esimerkiksi televisiossa esitettävien homovastaisten mielipiteiden vaikutusta lapsiin. Lisäksi lasten käyttäytymisen ongelmien näkeminen äidin seksuaalisen suuntautumisen seurauksena huoletti äitejä.

Tässä tutkimuksessa havaittiin sateenkaariperheiden kohdanneen syrjintää ja epäasiallista kohtelua. Perheen ulkopuoliset olivat sanoneet lapsille heidän vanhempiensa seksuaalisen identiteetin olevan väärä ja moraaliton. Lasten luokkatoverit kyseenalaistivat perhemuodon ja koulun suhtautuminen aiheutti ongelmia lapsille. Lapset olivat kokeneet kiusaamista ja nimittelyä. Vanhemmat raportoivat negatiivisia tai ongelmallisia kokemuksia terveydenhuollossa liittyen vanhempien seksuaaliseen suuntautumiseen.

Ympäröivä yhteisö ja yhteiskunta vaikuttivat sateenkaariperheiden äitien omaan sekä heidän lastensa hyvinvointiin sekä myönteisesti ja että kielteisesti. Perheen muodostamisen oikeudelliset ja poliittiset kysymykset aiheuttivat stressiä monille äideistä. Lapsen syntymän jälkeen etäännyttiin sateenkaariyhteisöstä. Oman perheen ja heteroperheiden kanssa oltiin yhä enemmän tekemisissä. Omasta yhteisöstä etääntyminen voi olla vaikeaa ja sillä saattaa olla vaikutusta äitien identiteettiin.

Äideillä oli aktiivisen toimijan rooli pyrkimyksissään vaikuttaa perheiden selviytymiseen perhesuunnitelulla, valmentamalla lapsia, ympäröivän yhteiskunnan tietoisuutta lisäämällä ja perheensä normaaliutta korostamalla. Perheen perustaminen suunniteltiin tarkoin ja raskaus oli tarkkaan harkittu päätös. Halu saada lapsia oli osa naisena olemisen identiteettiä, ei osa sukupuolista suuntautumista. Tässä tutkimuksessa nousi vahvasti esille äitien panostus siihen, että lapset pääsisivät helpommalla. Äidit toisaalta opettivat lapsilleen selviytymiskeinoja, toisaalta he opettivat ympäröivälle yhteiskunnalle tilanteestaan. Sateenkaariperheiden äideillä on tarve luoda normaaliuden tunne, jotta he voivat antaa lapsilleen positiivisen kokemuksen perheen identiteetistä.

Läheisten tuki oli tärkeää äidiksi tultaessa. Osa äideistä sai enemmän tukea sukulaisiltaan, osa ystäviltään. Sosiaalisissa tilanteissa sosiaaliset äidit jätettiin ulkopuoliseksi, vaikka itse he 
kokivat olevansa tasa-arvoisia vanhempia. Erityisesti sosiaalisen äidin menetykset, esimerkiksi lapsen kuollessa, jäivät näkymättömiksi, eikä häntä nähty surevana vanhempana.

Sateenkaariperheiden ja heteroperheiden äidit saivat yhteiskunnalta tasavertaista informaatiota ja tukea. Vaikka suurin osa äideistä oli tyytyväisiä saamaansa yhteiskunnalliseen ja terveydenhuoltojärjestelmän tukeen, osa sateenkaariperheen äideistä ei saanut kaipaamaansa tukea hoitohenkilökunnalta. Etenkään sosiaalista äitiä ei huomioitu terveydenhuollossa. Osa hoitohenkilökunnasta ja lääkäreistä osoitti empatian ja potilaskeskeisyyden puutetta. Eniten kritiikkiä äidit antoivat vanhempien ohjauksesta. Ohjaus oli suunnattu tilanteisiin, joissa on äiti ja isä. Tämän tutkimuksen tulosten perusteella voidaankin olettaa, että sateenkaarivanhempien kohtaamisessa on puutteita terveydenhuollossa.

Sosiaali- ja terveydenhuollossa tulee kohdella kaikkia asiakkaita tasavertaisesti, yksilöllisesti ja ilman syrjintää. Tämän tutkimuksen tuloksiin pohjaten voidaan todeta sen tarkoittavan sateenkaariperheiden kohtelua normaaleina perheinä sekä perheenjäsenten asiallista ja yksilöllistä kohtaamista.

\section{Sateenkaariperheiden äitien tuen tarpeet ja suositukset tuen tarpeisiin vastaamiseksi}

Tämän tutkimuksen tulosten perusteella voidaan tunnistaa sateenkaariperheiden äideillä olevan tuen tarpeissaan erityispiirteitä, jotka sosiaali- ja terveydenhuollon ammattilaisten on hyvä tunnistaa voidakseen vastata niihin:

\section{Perheen sisäisen vanhemmuuden ja parisub-} teen tukeminen. Sosiaali- ja terveydenhuollon ammattilaisten on tärkeää antaa sateenkaariperheiden vanhemmille tukea parisuhteen kuormittuessa sekä äitien rooleissa, joihin heillä ei ole ollut perinteistä mallia.

2. Äitien seksuaalisen identiteetin tukeminen. Sosiaali- ja terveydenhuollon palveluissa on huomionarvoista tunnistaa äitien omia sisäisiä ristiriitoja, joilla voi olla äitien terveyttä ja hyvinvointia heikentäviä vaikutuksia, heidän kohdatessaan vastoinkäymisiä seksuaaliseen suuntautumisensa vuoksi.
3. Perheen lähipiirin tukeminen, jotta he voivat tukea perhettä. Sosiaali- ja terveydenhuollon palveluissa on tärkeää pyrkiä tunnistamaan äitien sosiaalinen verkosto ja tukea myös ydinperheen ulkopuolisen verkoston säilyttämistä.

4. Vanhemmuuden tukeminen perheen ulkopuolelta. Äitien epävarmuutta ja pelkoa ulkopuolisten suhtautumisesta voidaan yhteiskunnan tukipalveluissa, kuten vertaistukiryhmissä, lievittää käsittelemällä negatiivisten kokemusten ja esimerkiksi mediassa käytävän keskustelun aiheuttamia tunteita.

5. Sosiaalisen äidin roolin vahvistaminen perheen ulkopuolelta. On tärkeää esimerkiksi lainsäädännön keinoin määritellä sosiaalisten äitien roolia yhteiskunnassa tasavertaisena vanhempana ja auttaa näin äitien identiteetin kehittymistä.

6. Perheen tunnistaminen ja normaaliuden tunteen tukeminen. Sosiaali- ja terveydenhuollon ammattilaisten on hyvä huomioida kaikenlaiset perherakenteet normaaleina perheinä heteronormatiivisesta ajattelusta luopuen. Normaaliuden tunteen tukemiseen sisältyy sellaisten käsitteiden käyttö äideistä, joita he itse haluavat itsestään käytettävän sekä pyrkimys arkisen perhe-elämän mahdollistamiseen.

7. Koulutusvastuun jakaminen sateenkaariperhemuodosta yhdessä äitien kanssa. Sateenkaariperheistä kertomisen ja asennekoulutuksen vastuu tulee ottaa huomioon sosiaali- ja terveydenhuollon tutkinto- ja täydennyskoulutuksessa, jotta äideille yksityishenkilöinä ei jäisi suurinta koulutuskuormaa.

\section{Jatkotutkimuksen tarve}

Tämä integratiivinen kirjallisuuskatsaus kertoo muualla kuin Suomessa toteutettujen tutkimusten perusteella sateenkaariperheiden äitien kokemasta perheidensä todellisuudesta osana yhteiskuntaa. Jatkossa on tutkittava empiirisesti suomalaisten sateenkaariperheiden äitien kokemusta perheidensä elämästä osana suomalaista yhteiskuntaa. 


\section{KIRJOITTAJIEN KONTRIBUUTIOT}

Apiainen, Åstedt-Kurki, Palonen ja Kylmä osallistuivat tutkimuksen suunnitteluun. Apiainen ja Kylmä osallistuivat aineiston keruuseen. Apiainen, Åstedt-Kurki, Palonen ja Kylmä analysoivat aineiston. Apiainen ja Kylmä kirjoittivat käsikirjoituksen. Åstedt-Kurki ja Palonen kommentoivat kriittisesti käsikirjoitusta.

Apiainen, R. Astedt-Kurki, P., Palonen, M., Kylmä, J. Experiences of mothers in rainbow families and issues that influence their families' lives - an integrative review Sosiaalilääketieteellinen aikakauslehti - Journal of Social Medicine 20 I 8: 55: 225-242.

The purpose of this integrative literature review is to describe the experiences of mothers in rainbow families, and issues that influence their families' lives based on existing research literature. This review is necessary, as it is important for health care personnel to identify different families and their realities. In addition, health care personnel need to have enough information about different families to be able to provide them with effective support. A systematic search was performed using CINAHL, Medline, PsycINFO, Linda, Arto and Medic databases, yielding 49 research articles from eight different countries. The material was analyzed thematically. The mothers' experiences of their families' lives as a part of society spanned three main dimensions: living in a family other than a traditional hetero family, living with prejudice due to having minority status, and coping as a rainbow family. Living in a family other than a traditional hetero family meant finding and maintaining a balance between mothers' roles, and living as a social mother and parent who is not recognized or identified. The mothers' experiences of living with the preconceptions related to their minority status revolved around three areas: fears about societal attitudes, en- counters with people with preconceptions, and experiences that encounters with these people had an effect on their family members' health and wellbeing. Survival as a rainbow family included a mother's activities to improve their survival, and surviving with varying degrees of social and societal support. Based on the results of this study, it is possible to identify the special needs that the mothers of rainbow families have regarding their parenting and intimate relationship, their sexual identity. Furthermore, their special needs focus on their social surroundings, the strengthening of the role of a social mother, the identification of the family and the feeling of normality, and the sharing the training responsibility on rainbow families together with mothers. In the future, empirical research is needed on the experiences of mothers of Finnish rainbow families on the lives of their families as part of Finnish society

Keywords: rainbow families, mothers, lesbianism, bisexuality, child-parent relationship, intimate relationship

Saapunut 21.6.2017

Hyväksytty 11.12.2017

\section{LÄHTEET}

1) Kirjoniemi A, Kajamies A. Sateenkaariperheen ja opettajan kohtaaminen. Kasvatus 2011;2: 144-154.

2) Aarnio K. Sateenkaariperheiden lasten vahvuudet ja haavoittuvuudet - kirjallisuuskatsaus. Väestöliiton Väestöntutkimuslaitoksen työpaperi 2014(6). Helsinki: Väestöliitto; 2014.

3) Jämsä J. Sateenkaariperheiden lasten hyvinvointi. Kirjassa: Lammi-Taskula J, Karvonen S, Ahlström S. (toim.) Lapsiperheiden hyvinvointi 2009. Helsinki: Yliopiston kirjapaino; 2009, 138-148.

4) Nikander C, Salin M, Hakovirta M. Kelpaavatko samaa sukupuolta olevat parit vanhemmiksi? Yhteiskuntapolitiikka 2016;81(5):516-527. 
5) Tahdon2013. Luettu 20.11.2014. http://www. tahdon2013.fi/uutiset/tasa-arvoinen-avioliittolakion-koko-suomen-asia/

6) Solantaus T. Homoseksuaalisten vanhempien lasten kehitys. Kirjassa: Jämsä J. (toim.) Sateenkaariperheet ja hyvinvointi, Käsikirja lasten ja perheiden kanssa työskenteleville. Jyväskylä: PS-kustannus; 2008, 72-85.

7) Tuovila T, Koivusilta M, Åstedt-Kurki P, Kylmä J. Nuorten kokemuksia elämästä sateenkaariperheessä - systemaattinen kirjallisuuskatsaus. Yhteiskuntapolitiikka 2017;82(5): 560-569.

8) Aarnio K, Kallinen K, Kylmä J ym. 2017. Sateenkaariperheiden lasten ja nuorten hyvinvointi ja kokemukset, Väestöntutkimuslaitoksen julkaisusarja D62/2017, Helsinki: Väestöliitto; 2017.

9) Ketokivi K. Torjuttu autonomia.

Lapsuudenperheen vieraantuneet siteet ja aikuisten lasten vaihtoehtoiset elämänpolut. Kirjassa:

Jallinoja R. (toim.) Vieras perheessä. Helsinki: Gaudeamus Helsinki University Press; 2009, $32-62$.

10) Jämsä J. Suomalaiset sateenkaariperheet. Kirjassa: Jämsä J. (toim.) Sateenkaariperheet ja hyvinvointi, Käsikirja lasten ja perheiden kanssa työskenteleville. Jyväskylä: PS-kustannus; 2008, 26-47.

11) Suomen perustuslaki 11.6.1999/731. http://www. finlex.fi/fi/laki/ajantasa/1999/19990731

12) Laki potilaan asemasta ja oikeuksista 17.8.1992/785. http://www.finlex.fi/fi/laki/ ajantasa/1992/19920785

13) Terveydenhuoltolaki 30.12.2010/1326. http:// www.finlex.fi/fi/laki/ajantasa/2010/20101326

14) Fessler DA, Mitty J, Mayer KH, ym. The 2010 health care act and barriers to effective health promotion among men who have sex with men. Sex Transm Dis 2012;39(6):449-452. https://doi.org/10.1097/OLQ.0b013e31824fc62a

15) Lim FA, Bernstein I. Promoting awareness of LGBT issues in aging in a baccalaureate nursing program. Nurs Educ Perspect 2012;33(3):170175.

https://doi.org/10.5480/1536-5026-33.3.170

16) Daniel H, Butkus R. Lesbian, gay, bisexual, and transgender health disparities: executive summary of a policy position paper from the American College of Physicians. Ann Intern Med 2015;163(2):135-137. https://doi.org/10.7326/M14-2482

17) McKay B. Lesbian, gay, bisexual, and transgender health issues, disparities, and information resources. Med Ref Serv Q 2011;30(4):393-401. https://doi.org/10.1080/02763869.2011.608971

18) Dodge B, Schnarrs P, Goncalves G, ym. The significance of privacy and trust in providing health-related services to behaviorally bisexual men in the United States. AIDS Educ Prev 2012;24(3):242-256. https://doi.org/10.1521/aeap.2012.24.3.242

19) McCann E, Sharek D, Higgins A, ym. Lesbian, gay, bisexual and trangender older people in Ireland: mental health issues. Aging Ment Health 2013;17(3):358-365. https://doi.org/10.1080/13607863.2012.751583

20) Müller A. Teaching lesbian, gay, bisexual and transgender health in a South African health sciences faculty: addressing the gap. BMC Med Educ 2013;13:174.

https://doi.org/10.1186/1472-6920-13-174

21) Eliason M, Dibble $S$, DeJoseph J. Nursing's silence on lesbian, gay, bisexual, and transgender issues. The need for emancipatory efforts. ANS Adv Nurs Sci 2010;33(3):206-218. https://doi.org/10.1097/ANS.0b013e3181e63e49

22) Moll J, Krieger P, Moreno-Walton L, ym. The prevalence of lesbian, gay, bisexual, and transgender health education and training in emergency medicine residency programs: what do we know? Acad Emerg Med 2014;21:608-611. https://doi.org/10.1111/acem.12368

23) Lim FA, Brown DV Jr, Justin Kim SM. Addressing health care disparities in the lesbian, gay, bisexual, and transgender population: a review of best practices. Am J Nurs 2014;114(6):24-34. https://doi.org/10.1097/01. NAJ.0000450423.89759.36

24) Lim F, Johnson M, Eliason M. A national survey of faculty knowledge, experience, and readiness for teaching lesbian, gay, bisexual, and transgender health in baccalaureate nursing programs. Nurs Educ Perspect 2015;36(3):144-152. https://doi.org/10.5480/14-1355

25) Chapman R, Zappia T, Shields L. An essay about health professionals' attitudes to lesbian, gay, bisexual and transgender parents seeking healthcare for their children. Scand J Caring Sci 2012; 26:33-339. https://doi.org/10.1111/j.1471-6712.2011.00938.x

26) Dorsen C. An integrative review of nurse attitudes towards lesbian, gay, bisexual, and transgender patients. Can J Nurs Res 2012;44(3):18-43.

27) Sabin J, Riskind R, Nosek B. Health care providers' implicit and explicit attitudes toward lesbian women and gay men. Am J Public Health 2015;105(9):1831-1841. https://doi.org/10.2105/AJPH.2015.302631

28) Nikander T. Sähköpostitiedonanto Tilastokeskuksesta 2.6.2017.

29) Kuosmanen P. Sateenkaarifamilistinen käänne ja suomalaisten sateenkaarivanhempien muuttuvat perhemuodot. Kirjassa: Kuosmanen P, Jämsä J. (toim.) Suomalaiset sateenkaariperheet sosiaali- ja terveyspalveluissa ja koulussa. Helsinki: Edita Prima Oy; 2007, 37-44.

30) Aarnipuu T. Sateenkaariperheen ABC. Luettu 17.11.2011. http://www.sateenkaariperheet.fi/ images/abc.pdf. 2010.

31) Jämsä J. Juridinen ja yhteiskunnallinen tilanne. Kirjassa: Jämsä J. (toim.) Sateenkaariperheet ja hyvinvointi, Käsikirja lasten ja perheiden kanssa työskenteleville. Jyväskylä: PS-kustannus; 2008, 60-71.

32) Laki rekisteröidystä parisuhteesta annetun lain 9 
\:n muuttamisesta 391/2009. http://www.finlex.fi/ fi/laki/ajantasa/2001/20010950\#L3P9.

33) Laki avioliittolain muuttamisesta 156/2015. http:// www.finlex.fi/fi/laki/alkup/2015/20150156

34) SETA. Avioliittolaki 2017. Luettu 21.6.2017. http://seta.fi/avioliittolaki/

35) Moring A. Oudot perheet: normeja ja ihanteita 2000-luvun Suomessa. Helsinki: Unigrafia; 2013.

36) Whittemore R. Combining evidence in nursing research. Methods and implications. Nurs Res 2005:54(1):59-62.

https://doi.org/10.1097/00006199-20050100000008

37) Whittemore R, Knafl K. The integrative review: updated methodology. J Adv Nurs 2005;52(5):546-553. https://doi.org/10.1111/j.1365-2648.2005.03621.x

38) Hopia H, Latvala E, Liimatainen L. Reviewing the methodology of an integrative review. Scand J Caring Sci 2016;30:662-669. https://doi.org/10.1111/scs.12327

39) Evans D. Overview of methods. Kirjassa: Webb C \& Ross B. (toim.) Reviewing Research Evidence for Nursing Practice: Systematic Reviews. Oxford: Blackwell Publishing; 2008, 137-148.

40) Hoitotyön tutkimussäätiö. Näyttöön perustuuva toiminta 2017. Luettu 21.6.2017. http://www. hotus.fi/jbi-fi/jbi-menetelmakirjasto

41) Thomas J, Harden A. Methods for the thematic synthesis of qualitative research in systematic reviews. BMC Med Res Methodol 2008;8(45). https://doi.org/10.1186/1471-2288-8-45

42) Graneheim UH, Lundman B. Qualitative content analysis in nursing research: concepts, procedures and measures to achieve trustworthiness. Nurse Educ Today 2004;24:105-112. https://doi.org/10.1016/j.nedt.2003.10.001

43) Stewart AM, Baker JD, Elliot D. The effects of pilonidal sinus wound on activities of living: thematic analysis of participant interviews. J Clin Nurs 2011;20:3174-3182. https://doi.org/10.1111/j.1365-2702.2011.03806.x

44) Gabb J.* Lesbian M/Otherhooh: Strategies of Familial-linguistic Management in Lesbian Parent Families. Sociology 2005;39(4):585-603. https://doi.org/10.1177/0038038505056025

45) Goldberg AE, Downing JB, Sauck CC.* Perceptions of children's parental preferences in lesbian two-mother households. J Marriage Fam 2008;70:419-434. https://doi.org/10.1111/j.1741-3737.2008.00491.x

46) Hequembourg A.* Unscripted motherhood: lesbian mothers negotiating incompletely institutionalized family relationships. J Soc Pers Relat 2004;21(6):928-990. https://doi.org/10.1177/0265407504047834

47) Goldberg AE, Perry-Jenkins M.* The division of labor and perceptions of parental roles: Lesbian couples across the transition to parenthood. J Soc Pers Relat 2007;24(2):297-318. https://doi.org/10.1177/0265407507075415

48) Vanfrausse K, Ponjaert-Kristofferssen I, Brewaeys
A. * Family functioning in lesbian families created by donor insemination. Am J Orthopsychiatry 2003;73(1):78-90.

https://doi.org/10.1037/0002-9432.73.1.78

49) Pelka S.* Sharing motherhood: maternal jealousy among lesbian co-mothers. J Homosex 2009;56:195-217.

https://doi.org/10.1080/00918360802623164

50) Goldberg AE, Smith JAZ.* The social context of lesbian mothers' anxiety during early parenthood. Parent Sci Pract 2008;8:213-239. https://doi.org/10.1080/15295190802204801

51) Perlesz A, McNair R.* Lesbian parenting: insiders' voices. Aust N Z J Fam Ther 2004;25(2):129-140. https://doi.org/10.1002/j.1467-8438.2004. tb00603.x

52) Dalton SE, Bielby DD.* "That's our kind of constellation" lesbian mothers negotiate institutionalized understandings of gender within the family. Gend Soc 2000;14(1):36-61. https://doi.org/10.1177/089124300014001004

53) Bos HMW, van Balen F, van den Boom DC.* Experience of parenthood, couple relationship, social support, and child-rearing goals in planned lesbian mother families. J Child Psychol Psychiatry 2004;45(4):755-764.

https://doi.org/10.1111/j.1469-7610.2004.00269.x

54) Gartrell N, Rodas C, Deck A, ym.* The USA National Lesbian Family Study: interviews with mothers of 10-year-olds. Fem Psychol 2006;16(2):175-192. https://doi.org/10.1177/0959-353506062972

55) Larsson A-K, Dykes A-K.* Care during pregnancy and childbirth in Sweden: Perspectives of lesbian women. Midwifery 2007;25:682-690. https://doi.org/10.1016/j.midw.2007.10.004

56) McClellan DL.* The "other mother" and second parent adoption. J Gay Lesbian Soc Serv 2001;13(3):1-21. https://doi.org/10.1300/J041v13n03_01

57) Spidsberg BD.* Vulnerable and strong - lesbian women encountering maternity care. J Adv Nurs 2007;60(5):478-486. https://doi.org/10.1111/j.1365-2648.2007.04439.x

58) Breshears D.* Coming out with our children: turning points facilitating lesbian parent discourse with their children about family identity. Communication Reports 2010;23(2):79-90. https://doi.org/10.1080/08934215.2010.511398

59) Maccio EM, Pangburn JA.* Self-reported depressive symptoms in lesbian birth mothers and comothers. J Fam Soc Work 2012;15:99-110. https://doi.org/10.1080/10522158.2012.662860

60) Ross LE, Steele LS, Sapiro B.* Perceptions of predisposing and protective factors for perinatal depression in same-sex parents. Journal of Midwifery \& Woman Health 2005;50:65-70. https://doi.org/10.1016/j.jmwh.2005.08.002

61) Wall M.* Hearing the voices of lesbian women having children. J GLBT Fam Stud 2011;7:93-108. https://doi.org/10.1080/1550428X.2011.537231

62) Padavic I, Butterfield J.* MOTHERS, FATHERS, AND "MATHERS; negotiating a lesbian co- 
parental identity. Gend Soc 2011;25(2):176-196. https://doi.org/10.1177/0891243211399278

63) Puckett JA, Horne SG, Levitt HM, ym.* Out in the country: rural sexual minority mothers. J Lesbian Stud 2011;15:176-186. https://doi.org/10.1080/10894160.2011.521101

64) Mikhailovich K, Martin S, Lawton S.* Lesbian and gay parents: their experiences of children's health care in Australia. International Journal of Sexuality and Gender Studies 2001;6(3):181-191. https://doi.org/10.1023/A:1011586417276

65) Rawsthorne ML.* Just like other families? Supporting lesbian-parented families. Australian Social Work 2009;62(1):45-60. https://doi.org/10.1080/03124070802626885

66) Golding AC.* Redefining the nuclear family: an exploration of resiliency in lesbian parents. J Fem Fam Ther 2006;18(1/2):35-65. https://doi.org/10.1300/J086v18n01_02

67) Bos HMW, van Balen F, van den Boom DC ym." Minority stress, experience of parenthood and child adjustment in lesbian families. J Reprod Infant Psychol 2004;22(4): 291-304. https://doi.org/10.1080/02646830412331298350

68) McNair R, Brown R, Perlesz A, ym.*. Lesbian parents negotiating the health care system in Australia. Health Care Women Int 2007;29:91114. https://doi.org/10.1080/07399330701827094

69) Röndahl G. Bruhner E, Linhe J.* Heteronormative communication with lesbian families in antenatal care, childbirth and postnatal care. J Adv Nurs 2009;65(11):2337-2344. https://doi.org/10.1111/j.1365-2648.2009.05092.x

70) Chapman R, Wardrop J, Freeman P, ym.* A descriptive study of the experiences of lesbian, gay and transgender parents accessing health services for their children. J Clin Nurs 2012;21:1128-1135. https://doi.org/10.1111/j.1365-2702.2011.03939.x

71) Renaud MT.* We are mothers too: childbearing experiences of lesbian families. J Obstet Gynecol Neonatal Nurs 2007;36(2):190-199. https://doi.org/10.1111/j.1552-6909.2007.00136.x

72) Ross LE, Steele LS, Epstein R.* Service use and gaps in services for lesbian and bisexual women during donor insemination, pregnancy, and the postpartum period. J Obstet Gynaecol Can 2006;28(5):505-511. https://doi.org/10.1016/S1701-2163(16)32181-8

73) Short L.* Lesbian mothers living well in the context of heterosexism and discrimination: resources, strategies and legislative change. Fem Psychol 2012;17(1):57-74. https://doi.org/10.1177/0959353507072912

74) Morris JF, Balsam KF, Rothblum ED.* Lesbian mothers and nonmothers: demographics and the coming-out process. J Fam Psychol 2002;16(2):144-156. https://doi.org/10.1037/0893-3200.16.2.144

75) Haimes E, Weiner K.* "Everybody's got a dad..." Issues for lesbian families in the management of donor insemination. Sociol Health Illn 2000;22(4):477-499. https://doi.org/10.1111/1467-9566.00215
76) Van Dam MAA.* Mothers in two types of lesbian families: stigma experiences, support and burdens. J Fam Nurs 2004;10(4):450-464. https://doi.org/10.1177/1074840704270120

77) Mercier LR, Harold RD.* At the interface: lesbian-parent families and their children's schools. Child Sch 2003;25(1):35-47. https://doi.org/10.1093/cs/25.1.35

78) Donaldson C.* Midlife lesbian parenting. J Gay Lesbian Soc Serv 2000;11(2/3):119-138. https://doi.org/10.1300/J041v11n02_06

79) Wilton T, Kaufmann T.* Lesbian mothers' experiences of maternity care in the UK. Midwifery 2000;17:203-211. https://doi.org/10.1054/midw.2001.0261

80) Hardesty JL, Oswald RF, Khaw L, ym. * Lesbian mothering in the context of intimate partner violence. J Lesbian Stud 2008;12(2-3):191-210. https://doi.org/10.1080/10894160802161364

81) Hardesty JL, Oswald RF, Khaw L, ym. * Lesbian/ Bisexual mothers and intimate partner violence: help seeking in the context of social and legal vulnerability. Violence Against Women 2011;17(1):28-46. https://doi.org/10.1177/1077801209347636

82) Oswald RF, Fonseca CA, Hardesty JL.* Lesbian mothers' counseling experiences in the context of intimate partner violence. Psychol Women Q 2010;34:286-296. https://doi.org/10.1111/j.1471-6402.2010.01575.x

83) Breshears D.* Understanding communication between lesbian parents and their children regarding outsider discourse about family identity. J GLBT Fam Stud 2011;7:264-284. https://doi.org/10.1080/1550428X.2011.564946

84) Lee E, Taylor J, Raitt F. “ “It's not me, it's them": how lesbian women make sense of negative experiences of maternity care: a hermeneutic study. J Adv Nurs 2010;67(5):478-486.

$85)$ Wojnar D.* Miscarriage experiences of lesbian couples. J Midwifery Womens Health 2007;52(5):479-485. https://doi.org/10.1016/j.jmwh.2007.03.015

86) Goldberg AE, Smith JAZ.* Stigma, social context, and mental health: lesbian and gay couples across the transition to adoptive parenthood. J Couns Psychol 2011;58(1):139-150. https://doi.org/10.1037/a0021684

87) Patterson J. * Families of the lesbian baby boom: maternal mental health and child adjustment. Journal of Gay \& Lesbian Psychotherapy 2001;4(3/4):91-107. https://doi.org/10.1300/J236v04n03_07

88) Bos HMW, Hakvoort EM.* Child adjustment and parenting in planned lesbian families with known and as-yet unknown donors. J Psychosom Obst Gynecol 2007;28(2):121-129. https://doi.org/10.1080/01674820701409793

89) Shapiro DN, Peterson C, Stewart AJ. * Legal and social contexts and mental health among lesbian and heterosexual mothers. J Fam Psychol 2009;23(2):255-262. https://doi.org/10.1037/a0014973 
90) Suter EA, Daas KL, Bergen KM.* Negotiating lesbian family identity via symbols and rituals. J F Issues 2008;29(1):26-47. https://doi.org/10.1177/0192513X07305752

91) DeMino KA, Appelby GA, Fisk DF.* Lesbian mothers with planned families: a comparative study of internalized homophobia and social support. Am J Orthopsychiatry 2007;77(1):165173.

https://doi.org/10.1037/0002-9432.77.1.165

92) Cacciatore J, Raffo Z.* An exploration of lesbian maternal bereavement. National Association of Social Workers 2011;56(2):169-177. https://doi.org/10.1093/sw/56.2.169

93) Gomm R, Needham G, Bullman A. 2000. Evaluating Research in Health and Social Care. London: Sage; 2000.

94) Braun V, Clarke V. Using thematic analysis in psychology. Qual Res Psychol 2006;3(2):77-101. https://doi.org/10.1191/1478088706qp063oa

95) Juvonen T. Varjoelämää ja julkisia salaisuuksia. Jyväskylä: Vastapaino; 2002.

96) Hagman S. Seitsemän kummaa veljestä. Kertomuksia suomalaisen homoseksuaalisuuden historiasta. Tallinna: Gaudeamus; 2016.

\section{RIIKKA APIAINEN}

TtM, osastonhoitaja

Kaarinan terveyskeskussairaala

\section{PäIVI ÅstedT-KURKI}

THT, professori,

Tampereen yliopisto

Yhteiskuntatieteiden tiedekunta

Terveystieteet, Hoitotiede

PSHP

Yleishallinto

Mira Palonen

TtT, yliopisto-opettaja

Tampereen yliopisto

Yhteiskuntatieteiden tiedekunta

Terveystieteet, Hoitotiede

JARI KYLMÄ

FT, TtL, dosentti

Tampereen yliopisto, Yhteiskuntatieteiden tiedekunta

Terveystieteet, Hoitotiede 